\title{
Quality Assessment of Traditionally Processed Kola, A Deli Meat of Tamil Nadu, India
}

\author{
P. Selvan* and R. Gayathri \\ Department of Poultry Technology, College of Poultry Production and Management, \\ TANUVAS, Mathigiri, Hosur - 635 110, India \\ *Corresponding author
}

\begin{tabular}{l} 
Ke y w o r d s \\
$\begin{array}{l}\text { Kola, Coarse } \\
\text { ground meat, } \\
\text { Cooking loss, Deli } \\
\text { meat }\end{array}$ \\
\hline Article Info \\
$\begin{array}{l}\text { Accepted: } \\
18 \text { May } 2019 \\
\text { Available Online: } \\
\text { 10 June } 2019\end{array}$ \\
\hline
\end{tabular}

\section{Introduction}

Vast majority of the population in India and their diverse food habits, cultures, tradition and religions offer great market for meat and meat products. The consumption pattern of meat products is primarily skewed towards traditional ones. In recent years, the demand for quality meat and meat products is constantly increasing in India due to enhanced meat consumption, changing socio-economic status, growing consciousness of consumers about their nutritional contribution, urbanization, women employment etc., In general, the country is endowed with great number of traditional meat products and or preparations due to herinherent ethnic diversity. These products/preparations are chiefly consumed along with the staple food as side dishes and play a significant role in social and religious events as well as considerably contribute to local economy. Some of these are popular at regional and or national level. Traditional meat and chicken based fast food products like meat balls, kebabs, tikka, chicken tandoori (roast), 
biryani, curries, pickles, enrobed and battered products are attracting greater consumer response in India. Goshtaba and rista, popular traditional Kashmiri products, are also being processed at fast food corners, restaurants, star hotels, etc., which are liked by many for their unique taste. Similarly, Nihari, a traditional dish of Delhi, is a stew consisting of slowcooked meat mainly from shank portion of beef or lamb and mutton, goat meat and chicken, along with bone marrow. Several authors have reviewed and/ discussed the status and importance of traditional meat and poultry products at various prestigious conferences (Kondaiah, 1996; Sushil Kumar and Anjaneyulu, 1998; Kesava Rao et al., 1999; Anjaneyulu et al., 2008).

Majority of these products are 'prepare, cook and serve' in nature. Due to the lack of storage stability, these products usually take part only in the menu of catering establishments. Conduct of organized scientific studies for their process standardization and product characterization, subsequent application of novel technological interventions to improve their storage stability, mechanizing their production in large scale, taking steps to popularizing and commercializing such products would not only significantly contribute to cater the ever increasing demand and also employment opportunities.

'Kola urundai' also known as 'Kola' is one of the popular coarse comminuted meat product of Tamil nadu, usually prepared either with gravy for accompanying staple food oras deep fat fried snack food. Traditionally several variants of this product is being marketed by the catering establishments in the state. The present study was carried out to choose the product recipe as well as process involved in the preparation of kola, based on sensory trails and to assess various quality attributes of the products prepared during refrigerated storage $\left(4 \pm 1^{\circ} \mathrm{C}\right)$.

\section{Materials and Methods}

This work was carried out in Meat, Poultry and Fish Processing Unit and Food and Industrial Microbiology Laboratory at College of Food and Dairy Technology, Koduveli to choose the recipe and process for preparation of kola.

This part specifically describes the raw material and ingredients used for preparation of kola, processing procedure adopted and techniques employed for measuring and analysing the parameters to attain the objective proposed in the study.

\section{Raw materials and ingredients}

Mutton was obtained from a FSSAI registered red meat and poultry processing unit functioning at Alamathi. Similarly, other ingredients like roasted gram powder, green chillies, chilli powder, karam masala, Fennel seeds, onion, coriander leaves, curry leaves, ginger, garlic, salt and oil were obtained from reputed, licensed super market.

\section{Chemicals, media, buffers and reagents}

All the chemicals used in the study were of analytical grade, from reputed national and international firms. Dehydrated culture media and broth used were obtained from Hi-media, Mumbai.

\section{Preliminary experiments to choose the 'recipe and process combination' for Kola}

For the standardization of recipe and process, the traditional knowledge on different recipes and processes of kola possessed by the caterers and homemakers were utilized for conducting preliminary experiments that are solely based on sensory trails. In this experiment, three recipe and processing procedure combinations of kola were gathered 
from the caterers and homemakers. By comparing the sensory attributes (colour, flavour, texture and overall acceptability) of products prepared out of these three combinations using a sensory panel comprising students and staff of College of Food and Dairy Technology, one recipe and process combination has been chosen based on sensory scores for further study.

\section{Evaluation of quality characteristics}

The deep fat fried kola samples prepared out of chosen combination of recipe and process (i.e. standardized combination) were subjected to microbial, sensory and physico-chemical analysis $45 \mathrm{~min}$ after the preparation and also during refrigerated storage $\left(4 \pm 1^{\circ} \mathrm{C}\right)$ at periodic intervals..

\section{Microbial quality}

Microbial quality of fried kola samples were evaluated based on Total Viable Count (TVC), Coliform Count (CC) and Staphylococcal Counts (SC).

All microbial groups were determined using pour plate method, following the procedures described by American Public Health Association (APHA, 1984).

Five gram of kola sample was weighed near flame in a sterile stomacher bag and made into small pieces with sterile forceps and scissors. $45 \mathrm{ml}$ of sterile peptone water (Hi media) was added to it and homogenized using stomacher for 2 minutes to get uniform homogenate. Decimal dilutions of the homogenate were prepared in sterile peptone water and appropriate serial dilutions were plated in duplicate. Different media and incubation time and temperature were used for counting different types of bacteria. All the work was carried out in a clean UV sterilized laminar air flow.

\section{Total viable count}

$23.5 \mathrm{~g}$ of Plate Count Agar (PCA) was suspended in one litre of distilled water, boiled to dissolve completely and sterilised by autoclaving at $121^{\circ} \mathrm{C}$ (15 $\mathrm{lb}$ pressure) for 15

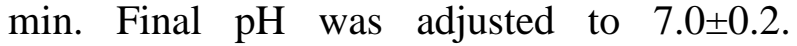
Sterilized petridishes in duplicate were inoculated with one $\mathrm{ml}$ of aliquots of appropriate dilutions. About 10-15 $\mathrm{ml}$ of sterile PCA maintained at $44-46^{\circ} \mathrm{C}$ was poured and inoculums were mixed properly by rotating plates. After solidification, plates were incubated at $37^{\circ} \mathrm{C}$ for $48 \pm 1$ hours. The number of colonies were multiplied by reciprocal of the dilution and expressed as $\log 10 \mathrm{cfu} / \mathrm{g}$ of sample.

\section{Coliform count}

$41.5 \mathrm{~g}$ of Violet Red Bile Agar (VRBA) was suspended in one litre of sterilized distilled water and boiled to dissolve the medium completely. Final pH was adjusted to 7.4 \pm 0.2 . Duplicate one $\mathrm{ml}$ volumes of suitable dilutions were placed in sterile petridishes and $10-15 \mathrm{ml}$ of boiled VRBA was added to each plate after cooling to $45^{\circ} \mathrm{C}$. Inoculums were mixed properly by rotating plates. After solidification, the plates were incubated at $37 \pm 1^{\circ} \mathrm{C}$ for $24 \mathrm{hrs}$. Red to pink colonies of 0.5 $\mathrm{mm}$ in diameter were counted and expressed as $\log 10 \mathrm{cfu} / \mathrm{g}$ of sample.

\section{Staphylococcal count}

$63 \mathrm{~g}$ of Baird Parker Agar base (BPA) base was suspended in $950 \mathrm{ml}$ distilled water, boiled to dissolve completely and sterilized by autoclaving at $121^{\circ} \mathrm{C}$ (15lb pressure) for 15 min. Final $\mathrm{pH}$ was adjusted to $7.0 \pm 0.2$. Prior to pouring the medium into the petridishes, 50 $\mathrm{ml}$ of egg yolk tellurite emulsion was added and mixed well. Sterilized petridishes in duplicate were inoculated with one $\mathrm{ml}$ aliquots of appropriate dilutions and $10-15 \mathrm{ml}$ of sterile 
BPA (egg yolk tellurite added) was poured to each plate after cooling to $45^{\circ} \mathrm{C}$. Inoculums were mixed properly by rotating plates. After solidification, the plates were incubated at $37 \pm 1^{\circ} \mathrm{C}$ for 24 hours. Black, shiny and regular shaped colonies were counted and expressed as $\log 10 \mathrm{cfu} / \mathrm{g}$ of sample.

\section{Sensory quality}

The fried kola samples were subjectively evaluated for colour, flavour, texture and overall acceptability on a sensory scale by a sensory evaluation panel comprising students and staffs of College of Food and Dairy Technology, Koduveli. For this purpose, a seven point hedonic scale was developed and used to evaluate the abovementioned sensory attributes.

The description of scale utilized in the study is given below.

\section{Physicochemical characteristics}

The fried kola samples were evaluated for physicochemical characteristics like $\mathrm{pH}$ and cooking loss/yield.

\section{pH}

$\mathrm{pH}$ of the fried kola samples were determined by homogenizing $10 \mathrm{~g}$ of sample with $90 \mathrm{ml}$ of distilled water in Ultra Turrex (IKA, Model $\mathrm{T}-25$, Germany) homogenizer for one min at $3000 \mathrm{rpm} . \mathrm{pH}$ of the suspension was recorded by immersing the combined glass electrode of digital $\mathrm{pH}$ meter.

\section{Weight loss or gain}

The fried kola samples were weighed after 45 min of preparation in electronic weighing balance. The differences in the weight of fried kola, before and after cooking, were expressed in percentage (\%) of weight loss/gain.

\section{Results and Discussion}

\section{Preliminary experiment}

Based on the results of the preliminary experiment conducted, the recipe and process that were chosen for further study has been mentioned in Table 1 and flow chart, respectively.

\section{Microbial quality}

The mean total viable, coliform and staphylococcal counts of kola as affected by refrigerated storage $\left(4 \pm 1^{\circ} \mathrm{C}\right)$ are presented in Table 2.

The mean TVC of fired Kola was $3.12 \pm 0.05$ $\log \mathrm{cfu} / \mathrm{g}$ of sample on day 0 i.e. $45 \mathrm{~min}$ after the preparation of kola and increased to $5.09 \pm 0.18 \mathrm{log} \mathrm{cfu} / \mathrm{g}$ on day 5 of refrigerated storage. The mean Coliform count was $1.02 \pm 0.54 \mathrm{log} \mathrm{cfu} / \mathrm{g}$ of sample on day 0 and then the count has increased until the end of study period.

Similarly, the mean staphylococcal count of kola was $1.96 \pm 0.62 \log$ cfu/g of sample on day 0 and the count reached $3.62 \pm 0.13 \log \mathrm{cfu} / \mathrm{g}$ during the end of storage period.

In contrary to the results of present study, Turhan et al., (2014) observed higher Staphylococcal aureus and Coliform counts in chicken meat balls. In the present study, the kola samples were deep fat fried and then stored whereas in Turhan's study the raw meat balls were subjected to refrigerated storage and analysis. This would be the reason why the lower counts were obtained in the present study.

It is important to note that the samples kept for analysis on day 7 had shown discernible signs of spoilage and hence, the samples were not subjected to analysis. 
Table.1 Recipe for preparation of Kola chosen through preliminary experiment

\begin{tabular}{|l|l|c|}
\hline S.No. & \multicolumn{1}{|c|}{ Ingredients } & Quantity \\
\hline $\mathbf{1}$ & Mutton & $500 \mathrm{gms}$ \\
\hline $\mathbf{2}$ & Roasted gram powder & $100 \mathrm{gms}$ \\
\hline $\mathbf{3}$ & Green chillies & $3 \mathrm{Nos}$. \\
\hline $\mathbf{4}$ & Chilli Powder & $1 \mathrm{TSP}$ \\
\hline $\mathbf{5}$ & Garam masala & $1 \mathrm{TSP}$ \\
\hline $\mathbf{6}$ & Fennel Seeds & $1 \mathrm{TSP}$ \\
\hline $\mathbf{7}$ & Onion & $2 \mathrm{Nos}$. \\
\hline $\mathbf{8}$ & Coriander leaves & qs* \\
\hline $\mathbf{9}$ & Curry leaves & qs* \\
\hline $\mathbf{1 0}$ & Ginger & $15 \mathrm{gms}$ \\
\hline $\mathbf{1 1}$ & Garlic & 20 gms \\
\hline $\mathbf{1 2}$ & Salt & $2.5 \%$ \\
\hline $\mathbf{1 3}$ & Oil & $750 \mathrm{ml}$ for frying \\
\hline
\end{tabular}

*quantity sufficient

\begin{tabular}{|c|c|c|c|}
\hline Table.2 Microbial quality of fried kola samples kept at refrigerated condition $\left(\mathbf{4} \pm \mathbf{1}^{\circ} \mathbf{C}\right)$ \\
\hline $\begin{array}{c}\text { Days of } \\
\text { storage }\end{array}$ & Total Viable Count & Coliform count & \begin{tabular}{c} 
Staphylococcal count \\
\hline Day 0
\end{tabular} \\
\hline Day 3 & $3.12 \pm 0.05$ & $1.20 \pm 0.54$ & $1.96 \pm 0.62$ \\
\hline Day 5 & $3.89 \pm 0.09$ & $2.63 \pm 0.09$ & $3.09 \pm 0.07$ \\
\hline
\end{tabular}

\begin{tabular}{|c|c|c|c|c|}
\hline \multicolumn{2}{|c|}{ Table.3 Sensory quality of fried kola samples kept at refrigerated condition $\left(\mathbf{4} \pm \mathbf{1}^{\circ} \mathbf{C}\right)$} \\
\hline $\begin{array}{c}\text { Days of } \\
\text { storage }\end{array}$ & Colour & Flavour & Texture & $\begin{array}{c}\text { Overall } \\
\text { Acceptability }\end{array}$ \\
\hline Day 0 & $6.50 \pm 0.22$ & $6.83 \pm 0.16$ & $6.68 \pm 0.21$ & $6.50 \pm 0.22$ \\
\hline Day 3 & $6.33 \pm 0.21$ & $5.66 \pm 0.21$ & $5.68 \pm 0.21$ & $6.17 \pm 0.17$ \\
\hline Day 5 & $5.83 \pm 0.17$ & $5.16 \pm 0.16$ & $5.50 \pm 0.22$ & $5.33 \pm 0.21$ \\
\hline
\end{tabular}

Table.4 Physio chemical quality of fried kola samples kept at refrigerated condition $\left(4 \pm 1^{\circ} \mathrm{C}\right)$

\begin{tabular}{|c|c|c|}
\hline Days of storage & pH & Weight loss/gain (\%) \\
\hline Day 0 & $6.50 \pm 0.22$ & $6.83 \pm 0.16$ \\
\hline Day 3 & $6.33 \pm 0.21$ & $5.66 \pm 0.21$ \\
\hline Day 5 & $5.83 \pm 0.17$ & $5.16 \pm 0.16$ \\
\hline
\end{tabular}


Seven point Hedonic Scale developed for sensory evaluation of fried Kola samples

\begin{tabular}{|c|c|}
\hline Score & Attitude of Panel Member \\
\hline $\mathbf{7}$ & Very much liked \\
\hline $\mathbf{6}$ & Moderately like \\
\hline $\mathbf{5}$ & Liked \\
\hline $\mathbf{4}$ & Neither liked nor disliked \\
\hline $\mathbf{3}$ & Disliked \\
\hline $\mathbf{2}$ & Moderately dislike \\
\hline $\mathbf{1}$ & Very much disliked \\
\hline
\end{tabular}

Flow Chart for Processing of Kola chosen through preliminary experiment

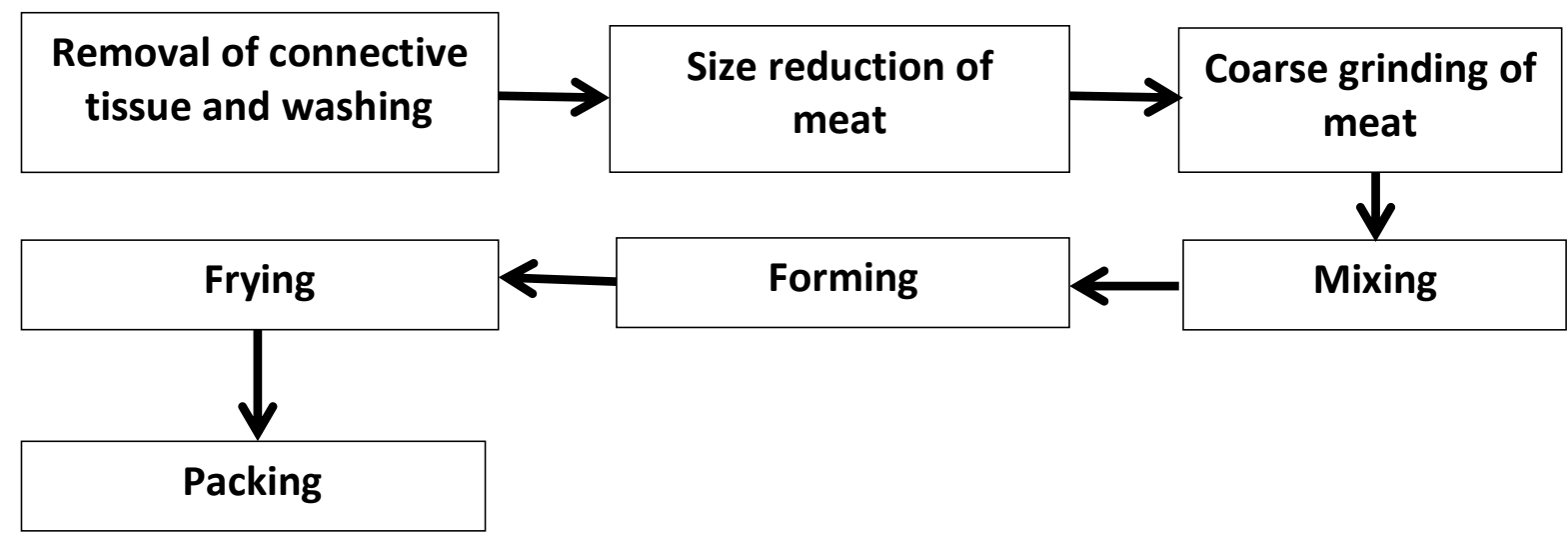

Sensory quality

The mean scores for sensory characteristics of fried kola as affected by refrigerated storage $\left(4 \pm 1^{\circ} \mathrm{C}\right)$ are presented in Table 3.

The mean colour, flavour, texture and overall acceptability scores were varied between 'very much liked' (score 7) and 'moderately like' (Score 6). Upon storage at $4 \pm 1^{\circ} \mathrm{C}$, the scores of all sensory attributes studied were gradually decreased as the storage days increased. The sensory scores obtained in the present study are in accordance with the results obtained by Turhan et al., (2014).

\section{Physicochemical quality}

The mean $\mathrm{pH}$ and cooking loss/gain values (in $\%)$ of fried kola as affected by refrigerated storage $\left(4 \pm 1^{\circ} \mathrm{C}\right)$ are presented in Table 4.

\section{pH}

On day 0 , the mean $\mathrm{pH}$ of kola was $5.58 \pm 0.11$ and increased to $6.57 \pm 0.05$ on day 5 of refrigerated storage $\left(4 \pm 1^{\circ} \mathrm{C}\right)$. With respect to $\mathrm{pH}$, the result of the present study is in concordance with the results of Can and Harun (2014) who found a $\mathrm{pH}$ of 6.2 in chicken meat balls.

\section{Cooking loss/gain}

The mean cooking loss of fried kola was $26.86 \pm 1.86 \%$. Conversely, Turhan et al., (2014) reported that the cooking loss of $39.94 \pm 0.31 \%$ while preparing chicken meat balls. The difference in the cooking loss between the studies might be attributed to the difference in the level of grinding. In the present study, the meat was subjected to coarse grinding which would have let to maintain the intact structure of tissues. This 
would have contributed to the better water holding and thereby decrease in cooking loss.

\section{References}

American Public Health Association, (1984). Compendium of methods for the microbiological examination of foods. Speck, M.L. (Ed), Washington, D.C.

Anjaneyulu, ASR, Thomas, R Gadekar, YP Lakshmanan, $\mathrm{V}$ and Mahapatra, CM. (2008). Indian Traditional Meat Products and Their Processing, Quality, Present Scenario and Future Prospects. Indian Food Industry 27(2): 53-59.

Can, O.P. and Harun, F. (2014). Shelf Life of Chicken Meat Balls Submitted to Sous Vide Treatment. Brazilian J. Poultry sci., Vol. 17 / No.2 / 137-144.

Kesava Rao, V. Mandal, P.K. and Pal, U.K. (1999). Traditional processing of meat and poultry products. In: Proc Nat Sem. Processing of meat, poultry and byproducts for value addition, 24-26 Feb, CFTRI, Mysore, pp 127-136.

Kondaiah, N. (1996.) Indian experience with indigenous chicken products. In: Proc. XX World's Poultry Congress, New Delhi, India, 1: 195-201.

Sushil Kumar and Anjaneyulu, ASR. (1998). Developments in traditional meat products and scope for their globalization. IVthInt Food Convention (IFCON-98), CFTRI, Mysore, 23-27th Nov Souvenir pp 230-231.

Turhan, S. Yazici, F. Saricaoglu, F.T., Mortas, M. and Genccelep, H. (2014). Evaluation of the Nutritional and Storage Quality of Meatballs Formulated with Bee Pollen. Korean J Food Sci Anim Resour. Vol. 34, No. 4, pp. 423-433.

\section{How to cite this article:}

Selvan, P. and Gayathri, R. 2019. Quality Assessment of Traditionally Processed Kola, a Deli Meat of Tamil Nadu, India. Int.J.Curr.Microbiol.App.Sci. 8(06): 3282-3288.

doi: https://doi.org/10.20546/ijcmas.2019.806.391 